\title{
Publisher Correction: Numerical methods every atomic and molecular theorist
} should know

\section{Barry I. Schneider(D) and Heman Gharibnejad}

Nature Reviews Physics (2019) https://doi.org/10.1038/s42254-019-0126-3 Published online 16 December 2019

The copyright information in this article was incorrect and was updated to "This is a U.S. government work and not under copyright protection in the U.S.; foreign copyright protection may apply".

https://doi.org/10.1038/s42254-020-0160-1 I Published online 21 February 2020

This is a U.S. government work and not under copyright protection in the U.S.; foreign copyright protection may apply 2020 